\title{
Estimating the Adoption Behaviour of Broccoli (Brassica oleracea var. italica) Cultivators with Respect to their Socio-economic Attributes in West Bengal
}

\author{
S. Sarkar ${ }^{1 *}$, K. Pradhan ${ }^{2}$ and S. Biswas ${ }^{3}$ \\ ${ }^{1,3}$ KVK CoochBehar, UBKV, Pundibari, CoochBehar, West Bengal (736 165), India \\ ${ }^{2}$ Dept. of Agricultural Extension, Faculty of Agriculture, UBKV, Pundibari, Cooch Behar, \\ West Bengal (736 165), India
}

\section{Article History}

Manuscript No. AR672

Received in $10^{\text {th }}$ March, 2014

Received in revised form $25^{\text {th }}$ September, 2014

Accepted in final form $28^{\text {th }}$ January, 2015

\section{Correspondence to}

"E-mail: drsurajitskr@gmail.com

\section{Keywords}

Broccoli, adoption behaviour, bio-physical, socio-economic factor

\begin{abstract}
The present study was conducted at Coochbehar-II block of West Bengal, India during 2011-12 and 2012-13 to estimate the adoption behaviour of the broccoli growers with respect to their biophysical, socioeconomic and socio psychological attributes. The study was conducted at Coochbehar-II block of West Bengal. The purposive as well as multistage random sampling procedures were followed to select the respondents of the study. The adoption behaviour was operationalized with the help of adoption index as a consequent variable. Fourteen antecedent variables were selected for the present study to explore the contribution in characterising the adoption behaviour of broccoli farmers. The data were collected with the help of structured interview schedule through personal interview method. The collected data were processed through descriptive statistics, correlation analysis, multiple regression analysis and factor analysis. The antecedent bio-physical variables like curd width, curd weight, yield, the socio-economic antecedent variables namely education, economic status, benefit cost ratio and horizontal expansion, the socio psychological antecedent variables like risk orientation and knowledge were found strongly associated with adoption behaviour of broccoli farmers. The predictor variables namely benefit cost ratio, effective farm size and economic status were strongly contributing in case of characterising the adoption behaviour of broccoli farmers. The study identified four distinct factors like biophysical and psychological orientation, socio-economic and educational exposure, socio-personal belongingness and family structure.
\end{abstract}

\section{Introduction}

In the era of globalisation, the quality assured high value vegetables play the pivotal role in case of delineating the sustainable livelihood pattern of the vegetable growers in our country. The high value vegetable has the potentiality to replace the traditional vegetable in the rural areas for generating empowerment and augmenting the annual earning of the rural family. Broccoli being a high value vegetable has the potentiality to replace the traditional vegetable like cauliflower due its market demand, nutritional efficiency and it can be grown to diversify the cropping pattern in the niche of climate change. Among the cole crops Broccoli is more nutritious than other cole crops. It is fairly rich in carotene and ascorbic acid and appreciable quantities of thiamine, riboflavin, niacin and iron (Thapa and Rai, 2012). Apart from this, Broccoli also contain anti cancer properties such as diindolylmethane and small amounts of selenium. The diindolylmethane found in Broccoli is a potent modulator of the innate immune response system with antiviral, anti bacterial and anti cancer activity. Broccoli also contains the compound glucoraphanin which can be processed into an anti cancer compound sulforaphane (Mukherjee and Mishra, 2012). Because of the medicinal and nutritive value there is a tremendous demand for Broccoli in domestic and foreign market. As a consequence the cauliflower growers of Coochbehar and other surrounding districts of terai zone of West Bengal are gradually adopting the Broccoli cultivation (Saha et al., 2006).

The above mentioned facts reveal that in West Bengal there is every scope to grow the high value vegetable like broccoli in scientific manner to ensure nutritional status and sustainable livelihood of rural poor. It would not be exaggerative that broccoli can also be an alternative to the rural farming 
community within a basket of high value vegetable. In the knowledge intensive society there is increasing demand for growing crop scientifically for better yield and quality (Reddy et al., 2011 and Singh et al., 2014). Scientific knowledge of growing such a sensitive high value vegetable inculcates the adoption and diffusion of information associated with broccoli cultivation. The adoption of any scientific practices is complex decision due to its multi co-linearity nature. So, adoption of scientific broccoli cultivation need special consideration of different biophysical socio economic and socio-psychological attributes of the growers. The food self sufficiency can not give impetus to the national economy by developing different mechanism to utilise the available resources but also the movement should be created to earn foreign exchequer by giving due importance to the exportable agricultural products (Saha et al., 2011). The intensive agricultural approach basically laden with ideas of high cost and high return enterprises had led our society to move pro-adoptive rather than pro-adaptive in regard to responding package of technologies recommended by the technology generating ends (Pradhan et al., 2009). The adoption of scientific broccoli cultivation is therefore coming under the prescriptive technology adoption towards market led approaches. Keeping all these in view the present paper envisages the adoption behaviour of the broccoli growers with respect to their social attributes.

\section{Materials and Methods}

The study was conducted at Coochbehar-II block of West Bengal, India for two consecutive years (2011-12 and 201213) and pooled data were taken for analysis. The purposive as well as multistage random sampling procedures were followed to select the respondents for the study. The district, block and village were selected purposively as the area had been highly potential with respect to broccoli cultivation and demographic advantages. An exhaustive list was prepared with the help of block and panchayat officials. From the exhaustive list of hundred respondents were selected through simple random sampling procedure. The adoption behaviour was operationalized and measured with the help of adoption index as a consequent variable. Fourteen antecedent variables were selected for the present study to explore the contribution in characterising the adoption behaviour of broccoli farmers. The data were collected with the help of structured interview schedule through personal interview method. The collected data were processed through descriptive statistics, correlation analysis, multiple regression analysis and factor analysis.

\section{Results and Discussion}

Table 1 presents the distribution of respondents according to the biophysical characters of broccoli and social attributes of broccoli growers. The variable curd width was distributed with a coefficient of variation value of 3.13 which shows higher consistency of the distribution. The biophysical attributes like curd weight and yield were distributed with higher level of consistency. The distribution pattern of socio economic variables like benefit cost ratio, education, farm size, educational aspiration, total farm size, effective farm size, economic status, risk orientation and knowledge showed the higher level of consistency in distribution. The variable like horizontal expansion was distributed with a medium level of consistency. The dependent variable namely adoption index was distributed with higher level of consistency.

\begin{tabular}{lcccc}
\hline \multicolumn{5}{l}{ Table 1: Distribution of the predictor and predicted variables } \\
\hline Variables & Range & Mean & Standard deviation & Coefficient of variation \\
\hline Adoption index $(\mathrm{Y})$ & $55-75.26$ & 61.8585 & 4.1552 & 6.72 \\
Curd width of Broccoli $\left(\mathrm{X}_{1}\right)$ & $8.5-10$ & 8.7425 & .2736 & 3.13 \\
Curd weight of Broccoli $\left(\mathrm{X}_{2}\right)$ & $734-790$ & 746.2250 & 9.6823 & 1.30 \\
Yield of Broccoli $\left(\mathrm{X}_{3}\right)$ & $30-34.84$ & 32.2948 & 1.2133 & 3.76 \\
Benefit cost ratio of Broccoli $\left(\mathrm{X}_{4}\right)$ & $3.66-4.11$ & 3.8196 & 0.0959 & 2.51 \\
Age $\left(\mathrm{X}_{5}\right)$ & $29-48$ & 38.4500 & 4.6576 & 12.11 \\
Education $\left(\mathrm{X}_{6}\right)$ & $3-14$ & 7.7375 & 2.4636 & 31.84 \\
Family size $\left(\mathrm{X}_{7}\right)$ & $4-8$ & 5.8000 & 1.1735 & 20.23 \\
Educational aspiration $\left(\mathrm{X}_{8}\right)$ & $4-10$ & 7.0375 & 2.0955 & 29.78 \\
Total farm size $\left(\mathrm{X}_{9}\right)$ & $4-16$ & 7.5750 & 2.0455 & 27.00 \\
Effective farm size $\left(\mathrm{X}_{10}\right)$ & $0.3-1.3$ & .7800 & .2088 & 26.77 \\
Economic status $\left(\mathrm{X}_{11}\right)$ & $7-16$ & 11.2125 & 2.7819 & 24.81 \\
Risk orientation $\left(\mathrm{X}_{12}\right)$ & $14-35$ & 26.5750 & 2.7225 & 10.24 \\
Knowledge $\left(\mathrm{X}_{13}\right)$ & $6-9.04$ & 6.7968 & .7912 & 11.64 \\
Horizontal expansion $\left(\mathrm{X}_{14}\right)$ & $1-9$ & 2.9000 & 1.6351 & 56.38 \\
\hline
\end{tabular}


Table 2 envisages the correlation coefficient of fourteen predictor variables with respect to adoption index. The biophysical parameters like curd width, curd weight, yield and benefit cost ratio had positively and significantly associated with the adoption behaviour of broccoli grower. The variable curd width and curd weight basically contributes to the yield and benefit cost ratio. In case of broccoli yield and benefit cost ratio are the function of curd width and curd weight. These four predictor variables are basically contributing to the relative advantage of the high value vegetable broccoli over the traditional vegetable cauliflower. So the higher degree of relative advantage leads to the positive adoption behaviour of broccoli grower with respect to scientific broccoli cultivation. These may be the plausible reason in case of explaining the significant and positive association between the four biophysical predictor variables and the adoption behaviour of broccoli growers. The socio-personal variable of education had significantly and positively associated with the adoption behaviour of broccoli growers. A movement in a positive direction on the ladder of education had made the respondent enough critical to the available choices. Education increases the exposure of an individual towards any new innovation that is why the variable education is positively associated with the broccoli growers. The variable economic status had also positively and significantly correlated with the adoption behaviour of the broccoli growers. The well off section of the society can take the venture to go along with the new innovation. They have the efficiency to become more venture some and cosmopolite in nature which ultimately help them to seek information regarding new practices. That's why the variable economic status had shown positive association of adoption behaviour of broccoli growers. Risk orientation of broccoli growers had also significantly and positively assorted with the adoption behaviour of broccoli growers. Risk or uncertainty is the inevitable phenomenon in case of adopting new innovation. The individual with higher level of risk orientation can predict the threat embedded with the innovation and simultaneously manage the enterprise with the help of their own acumen and resources. That's why the variable risk orientation had shown positive association of adoption behaviour of broccoli growers. The variable knowledge regarding the cultivation practices had recorded a positive and significant correlation with the adoption behaviour of broccoli growers. Knowledge about anything makes a trivial individual to a swashbuckling one. It increases the confidence of an individual to practise the innovation through building an epitome of cognitive attributes regarding any innovation. That's why the variable knowledge had shown positive association of adoption behaviour of broccoli growers. The variable horizontal expansion had also shown positive and significant correlation with the adoption behaviour of broccoli growers. Horizontal expansion implies the expansion of innovation from one end to another. The expansion and adoption are mutually exclusive phenomenon as expansion occurs through adoption. These may be the plausible reason behind the positive association between horizontal expansion of broccoli cultivation and the adoption behaviour of broccoli growers.

Table 3 explores the multiple regression analysis of adoption index with respect to fourteen predictor variables. The astounding fact is that the variables benefit cost ratio of broccoli enterprise, effective farm size for broccoli cultivation and economic status of broccoli grower are contributing significantly and positively in case of characterising the adoption behaviour of broccoli growers in presence of other predictor variable. The increased level of benefit cost ratio, effective farm size, economic status make a farmer more endowed with knowledge, exposure and new information. Ultimately it helps in case of taking risk to fully practise the new innovation in their own field with the help of their resources. Consequently these variables exert the positive impact in case of characterising the adoption behaviour of broccoli growers.

The $\mathrm{R}^{2}$ value being 0.862 , it is to infer that altogether the fourteen predictor variables had explained $86.20 \%$ variation embedded with the adoption behaviour of broccoli growers. Still $13.80 \%$ variations left unexplained. There is a scope to incorporate more number of contextual and realistic predictor variable in future study.

Table 4 reflects the factor analysis of fourteen predictor variables and one consequent variable for an intrinsic conglomeration of the variables to form a homophiles group

Table 2: Correlation coefficient of adoption index with respect to fourteen predictor variables

\begin{tabular}{lc}
\hline Variables & Coefficient of correlation $(\mathrm{r})$ \\
\hline Curd width of Broccoli $\left(\mathrm{X}_{1}\right)$ & $0.701^{* *}$ \\
Curd weight of Broccoli $\left(\mathrm{X}_{2}\right)$ & $0.627^{* *}$ \\
Yield of Broccoli $\left(\mathrm{X}_{3}\right)$ & $0.687^{* *}$ \\
Benefit cost ratio of Broccoli $\left(\mathrm{X}_{4}\right)$ & $0.872^{* *}$ \\
Age $\left(\mathrm{X}_{5}\right)$ & -0.098 \\
Education $\left(\mathrm{X}_{6}\right)$ & $0.345^{* *}$ \\
Family size $\left(\mathrm{X}_{7}\right)$ & 0.089 \\
Educational aspiration $\left(\mathrm{X}_{8}\right)$ & 0.179 \\
Total farm size $\left(\mathrm{X}_{9}\right)$ & 0.167 \\
Effective farm size $\left(\mathrm{X}_{10}\right)$ & 0.152 \\
Economic status $\left(\mathrm{X}_{11}\right)$ & $0.297^{* *}$ \\
Risk orientation $\left(\mathrm{X}_{12}\right)$ & $0.710^{* *}$ \\
Knowledge $\left(\mathrm{X}_{13}\right)$ & $0.697^{* *}$ \\
Horizontal expansion $\left(\mathrm{X}_{14}\right)$ & $0.567^{* *}$ \\
\hline${ }^{* *} p<0.01$ &
\end{tabular}




\begin{tabular}{lcccc}
\hline \multicolumn{4}{l}{ Table 3: Multiple regression analysis of adoption behaviour with respect to fourteen variables } & \\
\hline Variables & $\beta$ & 'b' & Standard Error of ' $\mathrm{b}$ ' & $\mathrm{t}$ \\
\hline Curd width of Broccoli $\left(\mathrm{X}_{1}\right)$ & .035 & 0.528 & 2.990 & 0.177 \\
Curd weight of Broccoli $\left(\mathrm{X}_{2}\right)$ & 0.093 & 0.040 & 0.079 & 0.503 \\
Yield of Broccoli $\left(\mathrm{X}_{3}\right)$ & 0.102 & 0.349 & 0.327 & 1.068 \\
Benefit cost ratio of Broccoli $\left(\mathrm{X}_{4}\right)$ & 0.714 & 30.948 & 5.631 & $5.496^{* *}$ \\
Age $\left(\mathrm{X}_{5}\right)$ & -0.045 & -0.040 & 0.048 & -0.832 \\
Education $\left(\mathrm{X}_{6}\right)$ & 0.069 & 0.116 & 0.120 & 0.971 \\
Family size $\left(\mathrm{X}_{7}\right)$ & -0.005 & -0.018 & 0.228 & -0.079 \\
Educational aspiration $\left(\mathrm{X}_{8}\right)$ & -0.007 & -0.015 & 0.115 & -0.129 \\
Total farm size $\left(\mathrm{X}_{9}\right)$ & 0.016 & 0.033 & 0.207 & 0.159 \\
Effective farm size $\left(\mathrm{X}_{10}\right)$ & -0.261 & -5.205 & 1.560 & $-3.336^{* *}$ \\
Economic status $\left(\mathrm{X}_{11}\right)$ & 0.339 & 0.507 & 0.155 & $3.261^{* *}$ \\
Risk orientation $\left(\mathrm{X}_{12}\right)$ & -0.014 & -0.021 & 0.128 & -0.161 \\
Knowledge $\left(\mathrm{X}_{13}\right)$ & -.084 & -0.443 & 0.530 & -0.835 \\
Horizontal expansion $\left(\mathrm{X}_{14}\right)$ & 0.116 & 0.295 & 0.169 & 1.751 \\
\hline
\end{tabular}

$\mathrm{R}^{2}=0.862^{* *} p<0.01$

Table 4: Factor analysis of adoption index and fourteen predictor variables

\begin{tabular}{lccccc}
\hline Variables & Factor loadings & Eigen value & \% of variance & Cumulative \% & \multicolumn{1}{c}{ Rename } \\
\hline Adoption index $(\mathrm{Y})$ & 0.893 & 5.261 & 35.074 & 35.074 & $\begin{array}{l}\text { Biophysical and } \\
\text { psychological } \\
\text { orientation }\end{array}$ \\
Curd width of Broccoli $\left(\mathrm{X}_{1}\right)$ & 0.814 & & & & \\
Curd weight of Broccoli $\left(\mathrm{X}_{2}\right)$ & 0.712 & & & & \\
Yield of Broccoli $\left(\mathrm{X}_{3}\right)$ & 0.846 & & & & \\
Benefit cost ratio of Broccoli $\left(\mathrm{X}_{4}\right)$ & 0.947 & & & & \\
Knowledge $\left(\mathrm{X}_{13}\right)$ & 0.835 & & & & \\
Horizontal expansion $\left(\mathrm{X}_{14}\right)$ & 0.555 & & & & \\
Risk orientation $\left(\mathrm{X}_{12}\right)$ & 0.769 & & & & Socio-economic \\
Education $\left(\mathrm{X}_{6}\right)$ & 0.583 & 3.176 & 21.172 & & exposure \\
Total farm size $\left(\mathrm{X}_{9}\right)$ & 0.880 & & & & \\
Effective farm size $\left(\mathrm{X}_{10}\right)$ & 0.819 & & & & \\
Economic status $\left(\mathrm{X}_{11}\right)$ & 0.908 & & & & Socio-personal \\
\hline Age $\left(\mathrm{X}_{5}\right)$ & -0.715 & 1.475 & 9.831 & & \\
Educational aspiration $\left(\mathrm{X}_{8}\right)$ & 0.703 & & & & \\
Family size $\left(\mathrm{X}_{7}\right)$ & 0.831 & 1.391 & 9.275 & 75.351 & Family structure \\
\hline
\end{tabular}

Factor loadings $>0.550$

or factor. The minimum level of factor loadings $(0.550)$ is considered to have such conglomeration. It's found that association of variables for factor-1 has been comprised of adoption index $\left(\mathrm{Y}_{1}\right)$, curd width $\left(\mathrm{X}_{1}\right)$, curd weight $\left(\mathrm{X}_{2}\right)$, yield $\left(\mathrm{X}_{3}\right)$, benefit cost ratio $\left(\mathrm{X}_{4}\right)$, knowledge $\left(\mathrm{X}_{13}\right)$, horizontal expansion $\left(\mathrm{X}_{14}\right)$ and risk orientation $\left(\mathrm{X}_{12}\right)$ and the factor can be renamed as biophysical and psychological orientation. The percent of variance explained by this factor has been 35.074 and eigen value is found 5.261. The $2^{\text {nd }}$ factor has encompassed 4 variables namely education $\left(\mathrm{X}_{6}\right)$, total farm size $\left(\mathrm{X}_{9}\right)$, effective farm size $\left(\mathrm{X}_{10}\right)$ and economic status $\left(\mathrm{X}_{11}\right)$ and can be renamed as socioeconomic and educational exposure.
This factor has explained $21.172 \%$ of variance and eigen value is found 3.176. The $3^{\text {rd }}$ factor comprises of variables namely age $\left(\mathrm{X}_{5}\right)$ and educational aspiration $\left(\mathrm{X}_{8}\right)$ and can be renamed as socio personal belongingness. This factor has explained $9.831 \%$ of variance with eigen value of 1.475 . The $4^{\text {th }}$ factor has reticulated with one variable farm size and can be renamed as farm structure. It has explained $9.275 \%$ of variance with eigen value 1.391 .

\section{Conclusion}

The biophysical and social correlates associated with adoption behaviour of broccoli growers in West Bengal, concluding that 
the bio-physical parameters obviously played a crucial role for adoption of scientific broccoli cultivation. Emphasis should also be given to the attributes like education, effective farm size, economic status, risk orientation and knowledge of the broccoli growers for its further promotion. The study infers that horizontal expansion is another key factor for delineating the diffusion of scientific broccoli cultivation.

\section{References}

Mukherjee, V., Mishra, P.K., 2012. Broccoli an underexploited neutraceutical. Science Research Reporter 2(3), 291294.

Pradhan, K., Acherjee, S.K., Adhikary, M.M., Sarkar, P., 2009. Analysis of the post adoption phases with respect to some critical agrotechniques of boro paddy (summer rice) with special emphasis on rejection phenomenon. Journal of Extension Education 14(1\&2), 97-104.

Reddy, C., Reddy, N., Jagdishwar, D., 2011. Persistence of chlorpyriphos and deltamethrin residues in cabbage. International Journal of Bio-resource and Stress
Management 2(3), 348-350.

Saha, A., Ghosal, R., Pradhan, K., Majumder, G., Das, J.K., 2011. Analysis of the adoption behaviour of the Mottra (Clinogyne dichotoma) grower in coochbehar district of West Bengal. Journal of Interacademicia 15(2), 324-329.

Saha, P., Chatterjee, R., Mukhopadhyay, D., 2006. Effect of boron and molybdenum on yield and quality of sprouting broccoli under terai agroecological region of West Bengal. Crop Research 32(3), 396-400.

Singh, A., Maji, S., Kumar, S., 2014. Effect of biofertilizers on yield and biomolecules of anti-cancerous vegetable broccoli. International Journal of Bio-resource and Stress Management 5(2), 262-268.

Thapa, U., Rai, R., 2012. Evaluation of sprouting Broccoli (Brassicae oleraceae var. italica) genotypes for gwowth, yield and quality. International Journal of Agriculture Sciences 4(7), 284-286. 